GRASAS Y ACEITES 70 (4)

October-December 2019, e328

ISSN-L: 0017-3495

https://doi.org/10.3989/gya.0939182

\title{
Physico-chemical properties and fatty acid composition of Chrozophora tinctoria seeds as a new oil source
}

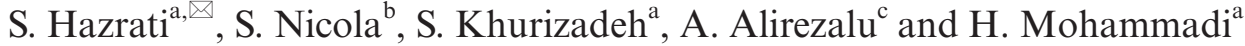 \\ a'Department of Agronomy, Faculty of Agriculture, Azarbaijan Shahid Madani University, 53714-161, Iran. \\ bepartment of Agricultural, Forest and Food Sciences, VEGMAP, University of Turin, 10095, Italy. \\ ¿Department of Horticultural Sciences, Faculty of Agriculture, Urmia University, Urmia, Iran. \\ Corresponding author: Saeid.hazrati@azaruniv.ac.ir
}

Submitted: 30 September 2018; Accepted: 21 December 2018; Published online: 22 July 2019

SUMMARY: Chrozophora tinctoria L., usually known as dyer's Croton, Turnsole or Giradol, has been used in various medicinal and food products for many years. However, no comprehensive research has been undertaken to assess its potential as a new seed oil crop. Therefore, the current study examined the fatty acid composition, physico-chemical properties and antioxidant activity of $C$. tinctoria seeds, grown in the southwest of Iran. The seed oil content was found to be $26.40 \%$. The extracted oil was analyzed for fatty acid composition using gas chromatography (GC). The results showed that unsaturated fatty acids accounted for almost $91 \%$ of the total fatty acids. Linoleic acid was the dominant fatty acid (76.68\%), followed by oleic acid $(13.99 \%)$ and palmitic acid $(5.32 \%)$. $\delta$-tocopherol was the major tocopherol in the oil, representing $70 \mathrm{mg} / 100 \mathrm{~g}$ oil. The total phenolic content (151.70 mg GAE per $100 \mathrm{~g}$ oil) and total flavonoid content (1.17 mg QE oil) were also determined in the extracted oil. The antioxidant activity was measured by a DPPH assay and expressed as $45 \%$ of the seed oil. Due to its high oil yield and high unsaturated fatty acid content, C. tinctoria could be regarded as a new source of edible oil.

KEYWORDS: Antioxidant activity; Chrozophora tinctoria; Fatty acids; Seed oil

RESUMEN: Propiedades físico-químicas y composición de ácidos grasos de las semillas de Chrozophora tinctoria como nueva fuente de aceite. Chrozophora tinctoria L., generalmente conocida como Cencila, o Tornasol, se ha usado en diferentes productos medicinales y alimenticios durante muchos años. Sin embargo, no se ha realizado una investigación exhaustiva para evaluar su potencial como un nuevo cultivo de semillas oleaginosas. Por tanto, en el presente estudio se evaluó la composición en ácidos grasos, las propiedades físico-químicas y la actividad antioxidante de las semillas de C. tinctoria del suroeste de Irán. Se encontró que el contenido de aceite de las semillas era del 26,40\%. El aceite extraído se analizó para determinar la composición en ácidos grasos mediante cromatografía de gases (GC). Los resultados mostraron que los ácidos grasos insaturados representaron casi el $91 \%$ del total de ácidos grasos. El ácido linoleico fue el mayoritario $(76,68 \%)$, seguido del oleico $(13,99 \%)$ y palmítico (5,32\%). El $\delta$-tocoferol fue el principal tocoferol siendo su valor de $70 \mathrm{mg} / 100 \mathrm{~g}$ de aceite de semillas de C. tinctoria silvestre. También fueron determinados en el aceite su contenido fenólico total (151,70 mg de GAE por $100 \mathrm{~g}$ de aceite) y el total de flavonoides (1,17 mg QE por $100 \mathrm{~g}$ de aceite). La actividad antioxidante se midió mediante DPPH y fue de $45 \%$ de aceite de semilla. Debido al alto rendimiento de aceite y al alto contenido de ácidos grasos insaturados, C. tinctoria podría considerarse como una nueva fuente de aceite comestible.

PALABRAS CLAVE: Aceite de semilla; Ácidos grasos; Actividad antioxidante; Chrozophora tinctoria

ORCID ID: Hazrati S https://orcid.org/0000-0001-7859-8610, Nicola S https://orcid.org/0000-0003-4458-5939, Khurizadeh S https://orcid.org/0000-0002-9811-422X, Alirezalu A https://orcid.org/0000-0002-5882-8981, Mohammadi H https://orcid.org/0000-0003-3907-8756

Citation/Cómo citar este artículo: Hazrati S, Nicola S, Khurizadeh S, Alirezalu A, Mohammadi H. 2019. Physicochemical properties and fatty acid composition of Chrozophora tinctoria seeds as a new oil source. Grasas Aceites $\mathbf{7 0}$ (4), e328. https://doi.org/10.3989/gya.0939182

Copyright: (C2019 CSIC. This is an open-access article distributed under the terms of the Creative Commons Attribution 4.0 International (CC BY 4.0) License. 


\section{INTRODUCTION}

Chrozophora belongs to the Euphorbiaceae family and consists of nine species (Marzouk et al., 2015). C. tinctoria has been used as therapeutic and emetic treatments as well as for fever and warts in traditional medicine (Delazar et al., 2006). The leaves, stems, and seeds of $C$. tinctoria have been used in both food and industrial products. The most conspicuous organ of the plant is its fruit. The fruit is a strange-looking capsule in the shape of 3 spherical bodies fused in a rather rounded-triangular structure. There are three obviate angular seeds per fruit, enclosed by a thin, carunculated apically, with a flat embryo and copious endosperm. They are $0.4 \mathrm{~cm}$ in size and grayto-light brown in color (Van Welzen1999).

Seed oils contain high amounts of tocopherols, which have been associated with polyunsaturated fatty acids which protect against oxidation and make them important bioactive compounds (Górnaś and Soliven, 2015). They are also members of the vitamin E family. Vitamin E protects humans from the oxidative stress interceded by reactive oxygen species (ROS). The main role of tocopherols in the food industry is to inhibit lipid oxidation and to prevent lipid oxidation in foodstuff during storage, which results in improving shelflife (Sattler et al., 2004; Azzi and Vitamin, 2006). Many phyto-chemical constituents have been found in different Chrozophora species, including alkaloids, coumarins (Abdel-Sattar, 1985), diterpenoids (Tabussum et al., 2013), phenylpropanoid glycosides (Mohamed 2001), phenolic acids, tannins, anthraquinones, saponins and xanthones (Usman et al., 2007) and flavonoids (Hawas 2007). In addition, it has been reported that $C$. tinctoria has antioxidant (Oke-Altuntas et al., 2017), antimicrobial (Usman et al., 2007) and anticancer (Jamil et al., 2012) characteristics as well as anti-inflammatory (Abdallah et al., 2015), anti-proliferative (Oke-Altuntas et al., 2017) and wound-healing (Maurya and Semwal, 2016) properties. Due to its unique geographical position and climate situation, Iran possesses a rich flora. Studies on economically important crops are of major importance for understanding development conditions and current use of these plants. Therefore, C. tinctoria was selected for this study. There has been a great increase in the number of oilseed plant studies regarding the major role of vegetable oils as energy sources in the human diet. To date, several studies have investigated the potential of some new plants in terms of oil quality (Mirghani et al., 1996; Mariod and Mirghani, 2017). To the best of our knowledge, there is no comprehensive study on the oil content and fatty acid composition of $C$. tinctoria, and accordingly, the current study was aimed to examine the oil content, fatty acid composition and antioxidant properties of C. tinctoria.

\section{MATERIAL AND METHODS}

\subsection{Plant sampling}

Mature, wild C. tinctoria were collected from Sepidan, Iran (Latitude $30^{\circ} 2^{\prime} 42.21^{\prime \prime} \mathrm{N}$ and longitude $52^{\circ} 16^{\prime} 34.44^{\prime \prime} \mathrm{E}$, at an altitude of $551 \mathrm{~m}$ above sea level), in 2017. The locations were marked by a Global Positioning System (GPS). The climate is cool and moist-to-semi-arid, with a mean-annual rainfall of $758 \mathrm{~mm}$ and a mean-annual temperature of $10^{\circ} \mathrm{C}$. The seeds were washed with sterile water, and then dried at ambient temperature for seven days before storing in a sealed container at $4{ }^{\circ} \mathrm{C}$ until oil extraction (for a maximum of 14 days).

\subsection{Oil extraction}

The seeds were removed from the fruits. The seeds were milled using a grinder to obtain a fine powder, and then they were subjected to Soxhlet extraction using $\mathrm{n}$-hexane for $8 \mathrm{~h}$. After extraction, the solvent was evaporated under reduced pressure at $60{ }^{\circ} \mathrm{C}$.

\subsection{Physico-chemical analysis}

The refractive index $\left(\right.$ at $25^{\circ} \mathrm{C}$ ) and free fatty acids (percentage in oleic acid), were determined according to the standard AOCS method (2009). Unsaponifiable matter was calculated according to the method defined by Sbihi et al., (2013). The theoreical iodine value was calculated according to the method described by Miyake and Yokomizo, (1998). The total protein content was determined according to the official method of the AOAC (2005) by the macro- Kjeldahl method using a sulphate-sodium sulphate-copper catalyst in digestion.

\subsection{Fatty acid profile}

The Fatty acids were transformed into their corresponding fatty acid methyl esters (FAME) as conferring to the Metcalf and Shmitz, (1966) method, and identified using a gas chromatography (Unicam 4600) equipped with a FID detector. Capillary silica column BPX70 $(30 \mathrm{~m} \times 0.22 \mathrm{~mm}$ i.d, $0.25 \mu \mathrm{m}$ film thickness (SGE)) was used as the stationary phase and $0.2 \mu \mathrm{l}$ of the FAME sample were injected into the chromatograph using a micro syringe. The carrier gas was helium with a head pressure of $18 \mathrm{psi}$. The injector and detector temperatures were adjusted to 250 and $300{ }^{\circ} \mathrm{C}$, respectively. The oven temperature was programmed to $160^{\circ} \mathrm{C}$ for $5 \mathrm{~min}$ and subsequently increased by $2.0^{\circ} \mathrm{C} / \mathrm{min}$ to $200^{\circ} \mathrm{C}$ and held for 40 minutes. The FAME samples were identified through comparison of standards (Aldrich or Sigma) and the closest match to the retention time data and mass spectra. The fatty acid patterns were calculated and evaluated from the total identified fatty acids. 


\subsection{Tocopherol profile}

The tocopherol composition was identified according to the AOCS method Ce 8-89 (2009) using high performance liquid chromatography (HPLC). Before to the HPLC analysis, the seed oil was diluted with hexane $(0.4: 10 \mathrm{w} / \mathrm{w})$ and $20 \mu \mathrm{L}$ samples were injected. The samples were analyzed with a (Waters, USA), equipped with a fluorescence detector. The operating conditions of the fluorescence detector were $\lambda$ excitation $295 \mathrm{~nm}$ and $\lambda$ emission $330 \mathrm{~nm}$. A normal phase column 5 Micron column $(4.6 \times 250 \mathrm{~mm})$ was used with hexane/isopropanol (99.5/0.5 v/v) as mobile phase. The system was operated isocratically at a flow rate of $1.3 \mathrm{~mL} / \mathrm{min}$. The identification of tocopherols ( $\alpha, \beta, \gamma$ and $\delta$-tocopherol) was conducted by comparing the HPLC retention time with those of standard compounds (Supelco, Bellefonte, USA) under the same operating conditions. The quantification of tocopherols was based on external standard curves of standard solutions of $\alpha, \beta, \gamma$ and $\delta$-tocopherol.

\subsection{Total phenolic content}

The total phenolic content was determined using Folin-Ciocalteu according to the method described by Kaur and Kapoor, 2002. The results of total phenolic content were estimated using a calibration curve with Gallic acid (Sigma-Aldrich, St Louis, EUA) and were expressed as $\mathrm{mg}$ of Gallic acid equivalents per gram of extract.

\subsection{Total flavonoid content}

The total flavonoid content was determined using aluminum chloride $\left(\mathrm{AlCl}_{3}\right)$ with quercetin as standard (Ordonez et al., 2006). In brief, $400 \mu \mathrm{l}$ of crude extract were added to $0.3 \mathrm{ml}$ distilled water followed by $5 \% \mathrm{NaNO}_{2}(0.03 \mathrm{ml})$. After $5 \mathrm{~min}$ of incubation at $25{ }^{\circ} \mathrm{C}, \mathrm{AlCl}_{3}(0.03 \mathrm{ml}, 10 \%)$ was added. Then, $0.2 \mathrm{ml}$ of $1 \mathrm{mM} \mathrm{NaOH}$ was added to the reaction mixture. Finally, the reaction mixture was diluted to $1 \mathrm{ml}$ with water and the absorbance was measured at $510 \mathrm{~nm}$. The total flavonoid content was calculated from a calibration curve and the results were expressed as mg quercetin $\mathrm{QE} / \mathrm{g}$ of extract.

\subsection{Antioxidant activity}

\subsubsection{DPPH assay}

The antioxidant activity was measured in accordance with the DPPH (2,2'-diphenyl-1picrylhydrazyl) free radical scavenging method (Akroum et al., 2010). Radical scavenging activity was evaluated based on the following equation:

Percent radical scavenging activity $=($ Abs control Abs sample)/Abs control $\times 100$

\subsection{2. $\beta$-carotene-linoleic acid assay}

The antioxidant activity of the extract was determined using the $\beta$-carotene linoleic acid model system (Jayaprakasha and Singh, 2001). The carotene solution was prepared by dissolving $0.2 \mathrm{mg} / \mathrm{mL}$ in chloroform. All the samples were assayed in triplicate. The antioxidant activity (AA) was calculated in terms of the percentage inhibition relative to the control, using the following equation:

$$
\mathrm{AA}=\left(\mathrm{R}_{\text {control }}-\mathrm{R}_{\text {sample }}\right) / \mathrm{R}_{\text {control }} \times 100
$$

\subsection{Chlorophyll and total carotenoids}

The chlorophyll and carotenoid contents were identified according to the methods described by Allalout et al., (2009) with some modifications.

\section{RESULTS}

\subsection{Seed and oil physico-chemical characteristics}

The seed and oil physico-chemical characteristics are given in Table 1 . The seeds contain $26.40 \%$ yellow oil. The results indicated that $C$. tinctoria was also rich in protein with $14 \%$ protein content. The unsaponifiable matter and the free fatty acid percentages were found to be 0.32 and $2.41 \%$, respectively. In addition, the refractive index was equal to 1.47. The iodine value was found to be $170.10 \mathrm{~g} / 100 \mathrm{~g}$ oil.

\subsection{Total phenolic, flavonoid, pigment contents and antioxidant activity}

As shown in Table 2, the total phenolic content was $151.70 \mathrm{mg}$ Gallic acid per $100 \mathrm{~g}$ oil. The total flavonoid content was found to be $1.17 \mathrm{mg} / \mathrm{g}$ oil.

TABLE 1. Physico-chemical properties of oils extracted from Chrozophora tinctoria

\begin{tabular}{lcc}
\hline Physico-chemical parameters & Unit & Content \\
\hline Weight of 1000 seeds & $\mathrm{g}$ & $15 \pm 0.98$ \\
Oil extraction yield & $\%$ & $26.40 \pm 0.29$ \\
Protein & $\%$ & $14 \pm 0.25$ \\
Color & & yellow \\
State at ambient temperature & & liquid \\
Refractive index $\left(25^{\circ} \mathrm{C}\right)$ & & $1.47 \pm 0.04$ \\
Unsaponifiable matter & $(\%, \mathrm{w} / \mathrm{w})$ & $0.32 \pm 0.02$ \\
Free fatty acid & as oleic $\%$ & $2.41 \pm 0.49$ \\
Iodine value & $\mathrm{g} / 100 \mathrm{~g}$ oil & $170.10 \pm 2.60$ \\
\hline
\end{tabular}

Mean value \pm standard error $(n=3)$. 
TABLE 2. Total phenolic, chlorophyll, and carotenoid contents and antioxidant activity of Chrozophora tinctoria seed oil.

\begin{tabular}{lccccc}
\hline \multicolumn{5}{c}{ OIL PROPERTIES } \\
\hline Cl (mg/100 g oil) & $\begin{array}{c}\text { B-Carotene linoleic acid } \\
\text { Inhibition (\%) }\end{array}$ & $\begin{array}{c}\text { TCC } \\
\text { (mg/100 g oil) }\end{array}$ & $\begin{array}{c}\text { TPC } \\
\text { (mg GAE/100 g oil) }\end{array}$ & $\begin{array}{c}\text { TFC } \\
\text { (mg QE/100 g oil) }\end{array}$ & $\begin{array}{c}\text { AA } \\
\text { (\%) (DPPH) }\end{array}$ \\
\hline $0.92 \pm 0.13$ & $42 \pm 0.57$ & $29.45 \pm 2.97$ & $151.70 \pm 0.61$ & $1.70 \pm 0.02$ & $45 \pm 3.11$ \\
\hline
\end{tabular}

Cl: Chlorophylls; TCC: Total carotenoid content; TPC: Total phenol content; TFC: Total flavonoid content; AA: Antioxidant activity. Mean value \pm standard error $(n=3)$.

The DPPH percentage after $30 \mathrm{~min}$ was found to be $45 \%$, which suggests high activity in neutralizing free radicals. The $\beta$-carotene/linoleate model system has been used as an important assay to assess the efficacy of anti-oxidative constituents for the inhibition of linoleic-acid-induced oxidation of $\beta$-carotene. $C$. tinctoria oil was capable of retarding the oxidation of $\beta$-carotene in the emulsion system (Table 2). The inhibition percentage of $\beta$-carotene degradation as expressed by percentage of discoloration of $C$. tinctoria oil extract was $42 \%$.

The results indicated that chlorophyll and carotenoid concentrations were 0.92 and $29.45 \mathrm{mg} / 100$ goil, respectively (Table 2 ).

\subsection{Fatty acid composition}

The fatty acid composition of $C$. tinctoria seed oil is shown in Table 3. According to the obtained results, the main fatty acids were unsaturated fatty acids, accounting for $91.45 \%$ of the total oil, including monounsaturated (oleic and palmitoleic acid) and polyunsaturated fatty acids (linolenic and linoleic acid). Hence, $C$. tinctoria seed oil contains high amounts of polyunsaturated fatty acids, such

TABLE 3. Fatty acid composition of oil extracted from Chrozophora tinctoria seeds.

\begin{tabular}{lc}
\hline Fatty acid & Content (\%) \\
\hline Palmitic acid (C16:0) & $5.32 \pm 0.047$ \\
Palmitoleic acid (C16:1) & $0.11 \pm 0.50$ \\
Stearic acid (C18:0) & $3.15 \pm 0.19$ \\
Oleic acid (C18:1) & $13.99 \pm 029$ \\
Linoleic acid (C18:2) & $76.68 \pm 0.16$ \\
Linolenic acid (C18:3) & $0.67 \pm 0.13$ \\
$\Sigma$ UFA & 91.45 \\
$\Sigma$ SFA & 8.43 \\
$\Sigma$ MUFA & 14.10 \\
$\Sigma$ PUFA & 77.35 \\
$\Sigma$ UFA : S SFA & 10.85 \\
$\Sigma$ MUFA: SPUFA & 0.18 \\
\hline
\end{tabular}

Note: UFA, unsaturated fatty acids; MUFA, monounsaturated fatty acids; PUFA, polyunsaturated fatty acids; SFA, saturated fatty acids. Mean value \pm standard error $(n=3)$. as linoleic acid, as the main fatty acid. The main fatty acids were identified as linoleic $(76.68 \%)$, oleic acid $(13.99 \%)$, palmitic acid $(5.32 \%)$ and stearic acid $(3.15 \%)$, (Table 3).

\subsection{Tocopherol composition}

The tocopherol contents of the C. tinctoria seed oils are presented in Table 4. The major tocopherol found in the seed oils were $\alpha, \delta$ - and $\gamma$-tocopherols and their amounts were found to be 4.20, 70 and 12.30 , respectively. $C$. tinctoria seed oil showed high concentrations of total tocopherols $(87.35 \mathrm{mg} / 100 \mathrm{~g})$.

\section{DISCUSION}

Seed oil content is an important indicator to measure industrial production efficiency. The high amount of oil in the seeds of this plant, as compared to other oilseeds, can be considered as an advantage for this plant to be used in different industrial applications. In terms of protein percentage, the current consequences are in agreement with those found by Mirghani et al., 1996 and Hussein and Mirghani, 2006). Hence C. tinctoria seeds have potential as a suitable source for animal feed due to fits high protein content.

The free fatty acid content in the extracted oil was observed to be less than that in C. brocchiana seed oil, which was reported by Hussein and Mirghani, (2006). Lower free fatty acid is associated with longer shelf-life in oils. Consequently, the oil can be classified among liquid oils and can be used extensively in the food industry. The refractive index of the C. tinctoria oil in our study was similar to C. brocchiana as reported by Ahmed (2015).

TABle 4. Vitamin E (tocopherols) composition of oil from Chrozophora tinctoria seeds.

\begin{tabular}{lc}
\hline Compounds & Concentration (mg/100 g oil) \\
\hline$\alpha$-tocopherol & $4.2 \pm 0.45$ \\
$\beta$-tocopherol & nd \\
$\gamma$-tocopherol & $12.3 \pm 0.91$ \\
$\delta$-tocopherol & $70.0 \pm 1.11$ \\
\hline Total Tocopherols & $87.5 \pm 1.37$ \\
\hline
\end{tabular}

Mean value \pm standard error $(n=3)$. 
Phenolic compounds play a significant role in flavor and extend the shelf-life of oil (Jorge and da Silva, 2015). The phenolic content obtained in the present experiment was higher than that of many other oilseeds. In a study done by Kozłowska et al., (2016), on the phenolic content in anise, nutmeg, white mustard, coriander and caraway determined 2.52, 3.21 and 1.50 and 0.20 and $0.78 \mathrm{mg} \mathrm{g}^{-1}$ oil, respectively. In addition, it has been described that higher phenolic content can protect oil against oxidation (Kozłowska et al., 2016). Flavonoids are polyphenol compounds that possess antioxidant properties. Carotenoids and chlorophylls are the key pigments in plants. In addition, these pigments are essential elements in auto-oxidation and photo-oxidation processes (Mínguez-Mosquera et al., 1991).

These pigments act as antioxidants in dark conditions (Psomiadou and Tsimidou 2002) and have medicinal and biological properties (Ranalli et al., 2000). Furthermore, C. tinctoria oil is yellow in color due to its high carotene, apocarotenal and annato contents, which are used in oil industries (Oomah et al., 2000).

These results recommend that the plant can be used as a good source of edible oil. Stearic and palmitic acid as saturated fatty acids accounted for $8.43 \%$ of the total oil. Similar results have been reported by other researchers who indicated that linoleic, oleic, stearic, and palmitic acids were the main fatty acids in C. brocchiana oil (Ahmed 2015). Similar outcomes have been obtained for other plant species such as Caryodendron orinocense with 75.13\% linoleic acid (Alfaro 1994) and C. plicata with 59.3\% linoleic acid (EL Bassam 2013). The reported linoleic level in C. tinctoria oil was significantly higher in comparison to other oilseeds. MUFA: PUFA, an indicator of oil autoxidation, was found to be 0.18 , much less than other oils (Asnaashari et al., 2015; Hashemi et al., 2018).

The results showed that $C$. tinctoria seed oil has high levels of tocopherols, and this content is higher than what has been obtained in oils such as sunflower $(44.0 \mathrm{mg} / 100 \mathrm{~g})$, sesame $(33.0 \mathrm{mg} / 100 \mathrm{~g})$, groundnut oil $(17.0 \mathrm{mg} / 100 \mathrm{~g})$ grape $(24-41 \mathrm{mg} / 100 \mathrm{~g})$, palm $(26 \mathrm{mg} / 100 \mathrm{~g})$ and saffron $(24-67 \mathrm{mg} / 100 \mathrm{~g})$, according to the Codex Alimentarius Commission (1999; 2009). Tocopherols are produced in plants in variable levels, and antioxidant activity varies between individual compounds. Tocopherols possess a protective effect against the oxidative stress related to metabolic syndrome and they are also essential for regular neurological function (Dias, 2012).

\section{CONCLUSION}

One of the most important findings in this study is the introduction of $C$. tinctoria as a new source of plant oil with a high yield $(26.40 \%)$. The results also indicated that $C$. tinctoria oil is rich in unsaturated fatty acids $(91.45 \%)$. In addition, the oil has a high level of polyunsaturated fatty acids $(77.35 \%)$, which is important in terms of health and medicine. The main fatty acids were C18:2 (76.68\%) and C18:1 (13.99\%). C. tinctoria seeds are a rich source of vitamin E (tocopherol) $(87.50 \mathrm{mg} / 100 \mathrm{~g}$ oil). Furthermore, its high total phenolic and flavonoid contents suggest that this oil is beneficial for resistance against oxidation, which leads to higher storage time. Overall, C. tinctoria oil can be used as a raw material oil in several industries in the near future.

\section{REFERENCES}

Abdallah HM, Almowallad FM, Esmat A, Shehata, IA, AbdelSattarEA. 2015. Anti-inflammatory activity of flavonoids from Chrozophora tinctoria. Phytochem. Lett. 13, 74-80. https://doi.org/10.1016/j.phytol.2015.05.008

Abdel-Sattar EA. 1985. A pharmacognostical study of Chrozophora plicata (Vahl.) growing in Egypt [M.Sc. thesis]. Cairo: Faculty of Pharmacy, Cairo University.

Ahmed MA. 2015. Nutritional value and characteristics of oil, protein and bioactive components of Chrozophora brocchiana seed. PhD Thesis. Khartoum North, Sudan, College of Agricultural Studies, Sudan University of Science and Technology. http://repository.sustech.edu/ handle/123456789/11281.

Akroum S, Bendjeddou D, Satta D, Lalaoui K. 2010. Antibacterial, antioxidant and acute toxicity tests on flavonoids extracted from some medicinal plants. J. Green Pharm. 4, 165-169.

Alfaro JM. 1994. Physico-chemical characteristics of the Barinas nut (Caryodendron orinocense Karst. Euphorbiaceae) crude oil. Arch. Latinoam. Nutr. 44 (3), 172-175.

Allalout A, Krichène D, Methenn K, Taamalli A, Oueslati I, Daoud D, Zarrouk M. 2009. Characterization of virgin olive oil from super intensive Spanish and Greek varieties grown in northern Tunisia. Sci. Hort. 120, 77-83. https:// doi.org/10.1016/j.scienta.2008.10.006

AOAC. 2005. Official Methods of Analysis. Association of OfficialAnalytical Chemist, 17th Ed Virginia 22201. USA.

AOCS. 2009. Official Methods and Recommended Practices of the American Oil Chemists' Society, J Am Oil Chem Soc, Champaing, IL

Asnaashari M, Hashemi SMB, Mahdavian Mehr H, Asadi Yousefabad SH. 2015. Kolkhoung (Pistacia khinjuk) hull and kernel oil as antioxidative vegetable oil with high oxidative stability and nutritional value. Food Technol. Biotechnol. 53, 81-86. https://doi.org/10.17113/ftb.53.01.15.3719

Azzi A, Stocker A. 2000. Vitamin E: non-antioxidant roles. Prog. Lipid Res. 39, 231-255. https://doi.org/10.1016/ S0163-7827(00)00006-0

Codex Alimentarius Commission. 1999. Codex-Stan 210: codex standard for named vegetable oils. Rome: FAO/WHO.

Codex Alimentarius Commission.2009. Codex-Stan 210: codex standard for named vegetable oils. Rome: FAO/WHO.

Delazar A, Talischi B, Nazemiyeh H, Rezazadeh H, Nahar L, Sarker SD. 2004. Chrozophorin: a new acylated flavone glucoside from Chrozophora tinctoria (Euphorbiaceae). Rev. Bras. Farmacogn. 16, 286-290. https://doi.org/10.1590/ S0102-695X2006000300002

Dias JS. 2012. Major classes of phytonutriceuticals in vegetables and health benefits: A Review. J. Nutr. Disord. Ther. 1 (31), 31-62.

EL Bassam, N. 2013. Energy plant species: their use and impact on environment and development. UK: Routledge Taylor and Francis Group Ltd.

Górnaś P, Soliven A, Seglina D. 2015. Seed oils recovered from industrial fruit byproducts are a rich source of tocopherols 
and tocotrienols: Rapid separation of $\alpha / \beta / \gamma / \delta$ homologues by RP-HPLC/FLD. Eur. J. Lipid Sci. Technol. 117, 773-777. https://doi.org/10.1002/ejlt.201400566

Hashemi SMB, Mousavi Khaneghah A, Barba FJ, Lorenzo JM, Rahman MS, Amarowicz R, Asadi Yousefabad SH, Dabiri Movahed M. 2018. Characteristics of Wild pear (Pyrus glabra Boiss) seed oil and its oil-in-water emulsions: a novel source of edible oil. Eur. J. Lipid Sci. Technol. 120, 1700284. https://doi.org/10.1002/ejlt.201700284

Hawas UW. 2007. Antioxidant activity of brocchlin carboxylic acid and its methyl ester from Chrozophora brocchiana. Nat. Prod. Res. 21, 632-640. https://doi.org/10.1080/1478 6410701371124

Hussein IH, Mirghani MES, CheMan YB. 2006. Physicochemical characteristics of Argessi (Chrozophora brocchiana), Kenaf (Hibiscus cannabinus) and Loofah (Luffa cylindrica) seed oils. Sudan J. Agric. Res. 6, 53-60.

Jamil M, Mirza B, Yasmeen A, Khan MA. 2012. Pharmacological activities of selected plant species and their phytochemical analysis. J. Med. Plant Res. 6, 5013-5022. https://doi. org/10.5897/JMPR09.259

Jayaprakasha GK, Singh RP, Sakariah KK. 2001. Antioxidant activity of grape seed (Vitis vinifera). Food Chem. 73 , 285-290. https://doi.org/10.1016/S0308-8146(00)00298-3

Jorge N, Silva AC da, Malacrida CR. 2015. Physicochemical characterisation and radical-scavenging activity of Cucurbitaceae seed oils. Nat. Prod. Res. 29, 2313-2317. https://doi.org/10.1080/14786419.2015.1007135

Kozlowska M, Gruczyńska E, Ścibisz I, Rudzińska M. 2016. Fatty acids and sterols composition, and antioxidant activity of oils extracted from plant seeds. Food Chem. 213, 450-456. https://doi.org/10.1016/j.foodchem.2016.06.102

Kaur C, Kapoor HC. 2002. Antioxidant activity and total phenolic content of some Asian vegetables. Int. J. Food Sci. Technol.37, 153-161. https://doi.org/10.1046/j.1365-2621.2002.00552.x

Liu Q, Yao H. 2007. Antioxidant activities of barley seeds extracts. Food Chem. 102, 732-737. https://doi.org/10.1016/j. foodchem.2006.06.051

Mariod AA, Mirghani MES, Hussein I. 2017. Unconventional Oilseeds and Oil Sources. Academic Press. https://doi. org/10.1016/B978-0-12-809435-8.00001-9

Marzouk MM, Hussein SR, Kassem MES, Kawashty SA, El Negoumy SIM. 2015. Phytochemical constituents and chemosystematic significance of Chrozophora tinctoria (L.) Raf. Nat. Prod. Res. 30,1537-1541. https://doi.org/10.1080 /14786419.2015.1045506

Maurya H, Semwal M, Dubey SK. 2016. Pharmacological evaluation of Chrozophora tinctoria as wound healing potential in diabetic Rat's model. Biomed. Res. Int. Article ID 7475124, 7 pages. https://doi.org/10.1155/2016/7475124

Metcalf LC, Shmitz AA, Pelka JR. 1966. Rapid preparation of methyl esters from lipid for gas chromatography analysis. Anal. Chem. 38, 514-515. https://doi.org/10.1021/ac 60171a016

Mínguez-Mosquera MI, Gandul-Rojas B, Montaño-Asquerino A, Garrido-Fernández J. 1991. Determination of chlorophylls and carotenoids by high-performance liquid chromatography during olive lactic fermentation. J. Chromatogr. A $\mathbf{5 8 5}$, 259-266. https://doi.org/10.1016/0021-9673(91)85086-U

Mirghani MES, Hussein IH, Dagne E, Bekele T. 1996. A comparative study of seed oils of Chrozophora brocchiana and Guizotia abyssinica. Bull. Chem. Soc. Ethiop. 10 (2), 161-164.

Miyake Y, Yokomizo K, Matsuzaki N. 1998. Rapid determination of Iodine value by $1 \mathrm{H}$ nuclear magnetic resonance spectroscopy. J. Am. Oil Chem. Soc. 75, 15-19. https://doi. org/10.1007/s11746-998-0003-1

Mohamed KS. 2001. Phenylpropanoid glucosides from Chrozophora obliqua. Phytochemistry 58, 615-618. https:// doi.org/10.1016/S0031-9422(01)00262-X

Oke-Altuntas F, Ipekcioglu S, Yaglioglu AS, BehcetL, Demirtas I. 2017. Phytochemical analysis, antiproliferative and antioxidant activities of Chrozophora tinctoria: a natural dye plant. Pharm. Biol. 55, 966-973. https://doi.org/10.1080/1 3880209.2016 .1277767

Oomah BD, Ladet S, Godfrey DV, Liang J, Girard B. 2000. Characteristics of raspberry (Rubus idaeus L.) Seed oil. Food Chem. 69, 187-193. https://doi.org/10.1016 /S0308-8146(99)00260-5

Ordonez AAL, Gomez JD, Vattuone MA, Isla MI. 2006. Antioxidant activities of Sechium edule (Jacq.) Swartz extracts. Food Chem. 97, 452-458. https://doi.org/10.1016/ j.foodchem.2005.05.024

Psomiadou E, Tsimidou M. 2002. Stability of virgin olive oil. 1. Autoxidation studies. J. Agric. Food Chem. 50, 716-721. https://doi.org/10.1021/jf0108462

Ranalli A, Modesti G, Patumi M, Fontanazza G. 2000. The compositional quality and sensory properties of virgin olive oil from a new olive cultivar-I-77. Food Chem. 69 , 37-46. https://doi.org/10.1016/S0308-8146(99)00233-2

Sattler SE, Gilliland LU, Magallanes-Lundback M, Pollard M, Della Penna D. 2004. Vitamin E is essential for seed longevity, and for preventing lipid peroxidation during germination. Plant Cell. 16, 1419-1432. https://doi.org/10.1105/ tpc. 021360

Sbihi HM, Nehdi IA, Tan CP, Al-Resayes SI. 2013. Bitter and sweet lupin (Lupinus albus L.) seeds and seed oils: a comparison study of their compositions and physicochemical properties. Ind. Crops Prod. 49, 573-579. https://doi. org/10.1016/j.indcrop.2013.05.020

Tabussum A, Riaz N, Saleem M, Ashraf M, Ahmad M, Alam U, Jabeen B, Malik A, Jabbar A. 2013. $\alpha$-glucosidase inhibitory constituents from Chrozophora plicata. Phytochem. Lett. 6 , 614-619. https://doi.org/10.1016/j.phytol.2013.08.005

Usman H, Musa YM, Ahmadu AA, Tijjani MA. 2007. Phytochemical and antimicrobial effects of Chrozophora senegalensis. Afr. J. Tradit. Complement. Altern. Med. 4, 488-494. https://doi.org/10.4314/ajtcam.v4i4.31242

Van Welzen PC. 1999. Revision and phylogeny of subtribes Chrozophorinae and Doryxylinae (Euphorbiaceae) in Malesia and Thailand. Blumea-Bio. Evol. Bio. Plants 44, 411-436. 